\title{
Reaching Kinesthetic Learners Over Distance
}

\author{
Katherine M. Gorbenko \\ Teachers College, Columbia University
}

Erickson $^{1}$, a New York City high school student, and I were working on his algebra homework over Zoom, specifically parabolas. We broke down the motion of a basketball and compared it to a parabola. He happened to have a small hoop on the back of his door and when he tried the motion himself, it was clear something clicked. You see, Erickson is a kinesthetic learner. During the pandemic, it has been challenging to design interactive materials and lessons for different types of learners. Distance learning disproportionality favors visual learners, followed by aural; however, reaching our kinesthetic learners has been a challenge. This is compounded by the fact that many students are either not aware of the types of learners they are, or they are not comfortable advocating for themselves - an issue not unique to k-12 students.

It applies to learners at every level and it requires our constant reflection as teachers and mentors. Three weeks into working with my student teacher I realized I had not reflected on this at all. In a debrief after a co-taught zoom class that had not gone to plan, he remarked, "I am taking lots of notes but I feel like I am not learning anything!"

He had of course observed the classes; he had even taught a two-week unit on his own that went well. This morning had only gone off track because the established patterns students had come to expect in the class were not followed. It was his first time leading the class in this course, and though he was aware of the pattern, he had never facilitated a lesson.

The next morning during our planning time I asked my student teacher what type of learner he was. He said no one had ever asked. We talked about times when he felt he was learning; each anecdote highlighted an experience where he was physically engaged in the task. In our coteaching environment with the social studies department, he was not responsible for planning lessons, only delivering parts of them. I asked him to write lesson plans for all the lessons, even though they were not his. Each lesson improved, and he began to master harder elements of the planning like language objectives.

This year has forced everyone to be a visual learner, but as teachers we should remember that is not a reality. I have reinstated surveys in classes that help me gauge learning styles, since then there has been more class engagement - and, hopefully, better learning.

Katherine M. Gorbenko is a fourth year ENL teacher at Forsyth Satellite Academy, a consortium transfer high school in the NYC DOE. She completed her MA in TESOL in 2017 and is currently completing her EdM in AL/Assessment at TC, Columbia University. Her area of interest is in writing assessment of ELL/MLL students, especially in high stakes norm and criterion referenced tests, such as the Regents and alternative assessments. In her current role she is part of a shared leadership school where she contributes to the Curriculum and Instruction

(C) 2021 Gorbenko. This is an open access article distributed under the terms of the Creative Commons Attribution

License, which permits the user to copy, distribute, and transmit the work provided that the original authors and source are credited.

1 Name has been changed 
team and is also the school's test coordinator. Correspondence should be sent to E-mail: km3090@tc.columbia.edu 